\title{
Jornalista escreve romance com trilha sonora
}

\author{
Deonisio da Silva \\ (Escritor e Doutor en Letras pela USP, diretor do Curso de Comunicação \\ Social da Universidade lstácio de Sá)
}

\section{Resenha do livro:}

Nêumanne Pinto, José. O Silêncio do Delator. Ed. A girafa. 2005.

Jamais encontrei entre leitores estrangeiros quem não ficasse deslumbrado com os autores brasileiros que thes apresento. $\mathrm{O}$ mais recente foi o poeta irlandês John Lyons, que trocou Londres, onde se doutorou em literatura, pelo interior de São Paulo, depois de apaixonar-se por uma brasileira que conheceu na Europa.

A cada novo livro, John Lyons exclama: "já foi traduzido?". Ele se desespera com o fato de não termos uma política editorial consistente para traduções. Considera a literatura brasileira uma das melhores do mundo, reconhecimento partilhado com outros experimentados tradutores.

Tenho mais um presente para John Lyons. Desta vez é $O$ Silêncio do Delator (Editora A Girafa, 541 páginas), romance do jornalista José Nêumanne Pinto que, leitor de Machado de Assis, adota ponto de vista semelhante ao de Memórias Póstumas

Nêumanne arma o velório mais engraçado do mundo, e a narração vai arrebatando o leitor. Não que sejam graças galhofas, não. São graças alcançadas por intermédio desde extraordinário recurso que é a palavra do romancista quando ele sabe manejá-la. E este é o caso. As memórias brotam sem parar, num caudal vertiginoso.

O romance dura o que dura o velório. Cenas antológicas podem ser detectadas em profusão. Algumas delas são simplesmente cinematográficas. É difícil falar em espaço tão exíguo de livro tão bom, alentado, denso e profundo. Mas escolhi esta, que acho emblemática.

Uma menina perdidamente apaixonada por um homem mais velho, não foi para cama com ele, dizendo, quando foi cantada, que queria apenas a amizade dele. Nêumanne sabe como poucos narrar uma boa história, certamente influenciado pela preparação no batente de jornalista que precisa escrever todos os dias. "Você acha possível uma menina como você se envolver com um homem mais velho?" "Como se envolver? Eu estou envolvida com você". "Não, quero dizer sexualmente". "Não somos apenas bons amigos?" "Estou perguntando se poderíamos não ser." "Para seu governo, eu já me apaixonei 
por um homem mais velho. Já tive vontade de ir para a cama com ele, mas não fui. Mas você vai para o túmulo sem saber quem foi". "Pobre de mim", ele diz. No enterro do professor universitário João Miguel, o protagonista silencioso do velório, dá-se algo surrealista. No caixão, o morto segue acompanhado de Coelho, personagem impagável. E este diálogo brota numa cena que bem merece fechar o romance. Entre a pá de cal e uma rosa vermelha jogada sobre o caixão, eis o que acontece:

"Caía esse último dia, mas todos os presentes viram muito bem o fulgor boreal da pele branca da moça que se despiu rapidamente, jogando blusa, saia, sapatos e meias na grama. Quando tirou a calcinha preta e a lançou sobre o caixão meio coberto de terra, seus pêlos públicos refletiam os últimos raios do sol, o fulgor do dia extinto. Fazia-se tarde. Era apenas o fim".

O romance retoma o contexto dos anos sessenta, a década que mudou tudo, fechando um memorial de reflexões no velório de um dos membros da patota de adolescentes que, quarenta anos depois, relembram os já célebres fracassos daquela geração.

Em perfeita homologia com o Brasil contemporâneo, o romance de Nêumanne deu prosa fascinante ao constatado pela síntese poética de Pedro Paulo de Sena Madureira em Vítimas da Luz:

"Temos saudade?/ Não. Temos raiva./ Erramos tudo/ e confessamos./ Confundimos as trevas,/ somos pedras em guerra./ Todas as estradas nos desgarram,/os abismos nos reconduzem".

Os Beatles e Bob Dylan comparecem à narrativa para dar-lhe silenciosa trilha sonora. 